\title{
REACTION OF PASSION FRUIT GENOTYPES TO THE COMPLEX Meloidogyne incognita AND Fusarium solani ${ }^{1}$
}

\author{
LEANDRO DE SOUZA ROCHA ${ }^{2 *}$, ADELICA APARECIDA XAVIER $^{3}$, REGINA CÁSSIA FERREIRA RIBEIRO $^{3}$
}

\begin{abstract}
The interaction between Meloidogyne and Fusarium can alter the resistance behavior of passion fruit genotypes. The study was aimed to evaluate the reaction of genotypes of Passiflora spp. to Meloidogyne incognita race 3 (Mi)-Fusarium solani $(F s)$ complex. The assay was carried using RBD in the factorial arrangement: 10 genotypes (BRS-SC, M-19-UFV, P. alata, P. nitida, P. giberti, P.setacea, P. mucronata, $P$. murifolia, $P$. cincinnata, $P$. ligularis $) \times 3$ treatments $(M i, M i+F s, F s)$. After 180 days of planting the reaction to $M i$ was determined by $\mathrm{RF}(\mathrm{Pi} / \mathrm{Pf})$ and to $F s$ by lesions size in roots and stems. According to the criteria of Oostenbrink and Moura and Regis, BRS-SC, M-19-UFV. $P$. alata and $P$. cincinnata behaved as resistant and $P$. giberti as susceptible. According to the Taylor and Sasser, BRS-SC, M-19-UFV, P. alata, P. cincinnata and $P$. giberti behaved as resistant, moderately resistant, moderately suscetible and susceptible, respectively. Lower percentage of plants with symtoms of $F s$ was found in $P$. mucronata, $P$. nitida, $P$. setacea, $P$. cincinnata and M-19-UFV In the presence of both pathogens, M-19-UFV, $P$. alata and $P$. nitida were those with larger lesion. In the presence de Fs, BRS-SC, $P$. alata, $P$. cincinnata and $P$. ligularis showed the largest lesions.
\end{abstract}

Keywords: Root-knot nematode. Resistance. Collar rot. Genotypes. Passiflora spp.

\section{REAÇÃO DE GENÓTIPOS DE MARACUJAZEIRO AO COMPLEXO Meloidogyne incognita E Fusarium solani}

RESUMO - A interação Meloidogyne-Fusarium pode alterar o comportamento de resistência de genótipos de maracujazeiro. Objetivou-se, neste trabalho avaliar a reação de genótipos de Passiflora ao complexo Meloidogyne incognita raça 3 e Fusarium solani. O experimento foi conduzido em DBC com esquema fatorial 10x3, sendo dez genótipos de Passiflora, (híbrido BRS Sol do Cerrado, seleção-M-19 da UFV, P. alata, P. nitida, $P$. giberti, $P$. setacea, $P$. mucronata, $P$. morifolia, $P$. cincinnata e $P$. ligularis e três tratamentos, $M$. incognita raça 3, M. incognita + Fusarium solani e $F$. solani. Após 180 dias do plantio e inoculação dos patógenos, avaliou-se a reação a $M$. incognita por meio do fator de reprodução- $(\mathrm{FR}=\mathrm{Pi} / \mathrm{Pf})$ e variáveis nematológicas e a reação a $F$. solani pelo tamanho das lesões nas raízes e caules. De acordo com os critérios de Oostenbrink e de Moura e Regis, 'BRS-Sol do Cerrado', M-19-UFV, P. alata e P. cincinnata foram resistentes e P. giberti foi suscetível a M. incognita raça 3. De acordo com Taylor e Sasser, 'BRS-Sol do Cerrado', M-19UFV, $P$. alata, $P$. cincinnata e $P$. giberti foram resistente, moderadamente, moderadamente suscetível e suscetível, respectivamente, ao nematoide. Menores porcentagens de plantas com sintomas de Fusarium foi encontrada em P. mucronata, $P$. nitida, P. setacea, $P$. cincinnata e M-19-UFV. Na presença de ambos os patógenos, M-19-UFV, $P$. alata e $P$. nitida foram os que apresentaram maior tamanho de lesão. Na presença de $F$. solani, 'BRS-Sol do Cerrado', $P$. alata, $P$. cincinnata e $P$. ligularis apresentaram as maiores lesões causadas pelo fungo.

Palavras chaves: Nematoide das galhas. Resistência. Podridão do colo. Genótipos. Passiflora spp.

\footnotetext{
*Corresponding author

${ }^{1}$ Received for publication in 05/12/2020; accepted in 05/25/2021.

Paper extracted from the masters dissertation of the first author.

${ }^{2}$ Embrapa Cassava \& Fruits, Empresa Brasileira de Pesquisa Agropecuária, Cruz das Almas, BA, Brazil; leandro.rocha@embrapa.br - ORCID: 0000-0002$8759-4846$.

${ }^{3}$ Department of Agricultural Sciences, Universidade Estadual de Montes Claros, Janaúba, MG, Brazil; adelica@unimontes.br - ORCID: 0000-0001-9814-4587, regina.ribeiro@unimontes.br - ORCID: 0000-0001-5138-8402.
} 


\section{INTRODUCTION}

Brazil is the largest passion fruit producing country, with approximately 593 thousand $\mathrm{Mg}$ (IBGE, 2019). However, low technological level and phytosanitary problems hinder higher production for this crop (FALEIRO; JUNQUEIRA; BRAGA, 2006; GARCIA et al., 2008).

Phytonematodes and soil fungi stand out among the phytosanitary problems in this crop. Meloidogyne incognita (Kofoid and White) Chitwood, 1949, is the most important among these nematodes, because it is responsible for decreases in vegetative development of plants of the genus Passiflora (El-MOOR et al., 2009). Fusarium solani (Mart.) Sacc is considered the main causing agent of collar rot disease in passion fruit plants. According to Ponte et al. (1998), this fungus is present in all passion fruit producing states of Brazil, causing death of the plants even before they reach two years of age. Dariva (2011), in a study to identify Fusarium spp. associated with early death of plants in passion fruit orchards in northern Minas Gerais, Brazil, found higher frequency of $F$. solani among the isolates studied.

The management of diseases caused by soil phytopathogens, such as $F$. solani and $M$. incognita, is done, mainly, by using resistant cultivars. However, the interaction Meloidogyne-Fusarium can change the resistance reaction in genotypes of passion fruit plants, making the use of these materials difficult and causing low crop yields. Wild Passiflora spp. commonly present sources of resistance to Meloidogyne spp. (CASTRO et al., 2010) and could be used as rootstocks for commercial varieties, allowing for the control of this pathogen. However, according to Fischer et al. (2005a) and Roncatto et al. (2004), all varieties of cultivars and wild plants of $P$. edulis (purple passion fruit) and $P$. edulis f. flavicarpa (yellow passion fruit) present some level of susceptibility to $F$. solani, since a higher resistance to the collar rot disease has been observed in $P$. alata, $P$. giberti, $P$. quadrangularis, $P$. macrocarpa, $P$. caerulia, and $P$. nitida (FISCHER et al., 2010).

Several studies show that the reaction of plants to fungi can be changed when plants are infected with Meloidogyne spp. (ROCHA, et al., 2018; ABD-EL-FATTAH et al., 2012; CARNEIRO; RAMALHO; PEREIRA, 2010). The presence of this nematode can increase damages in species susceptible to fungi and changes the phenotype of resistance in resistant species to a phenotype of susceptibility (FISCHER et al., 2010). However, information on the reaction of varieties of passion fruit plants to the action of $M$. incognita and $F$. solani, alone or in combination, are still very divergent due to the genetic variability of the plant material and the genetic variability of species and populations of the nematode and fungus.

The objective of this work was to evaluate the resistance level of 10 passion fruit genotypes to $M$. incognita race 3 and $F$. solani, inoculated alone or in combination.

\section{MATERIAL AND METHODS}

The work was developed in the State University of Montes Claros (UNIMONTES), Janaúba campus, Janaúba, Minas Gerais (MG), Brazil, from March 7 to September 7, 2012. The mean minimum and maximum temperatures during the conduction of the experiment were, respectively, $18.57^{\circ} \mathrm{C}$ and $32.31{ }^{\circ} \mathrm{C}$.

The experiment was conducted in a greenhouse, using a randomized block design in a $10 \times 3$ factorial arrangement with six replications. Ten genotypes of the genus Passiflora were used: 'BRS Sol do Cerrado' (yellow passion fruit hybrid from the GA-2 selection and MA (from the Redondão selection); selection-M-19 of the Federal University of Viçosa (UFV), MG, Brazil; P. alata; P. nitida; P. giberti; P. setacea; P. mucronate; P. morifolia Mast; $P$. cincinnata, and $P$. ligularis. The treatments were: $M$. incognita race $3 ; M$. incognita + Fusarium solani; and $F$. solani. The hybrid was obtained from seeds provided by the Brazilian Agricultural Research Corporation (Embrapa), P. alata was obtained from seeds of fruits marketed in Janaúba, and the other genotypes were obtained from the Sector of Fruit Production of the UFV. The control treatment consisted of the tomato cultivar "Kada", which was used as standard of viability of the inoculum of $M$. incognita raça 3.

A pure population of $M$. incognita race 3 was used in the experiment, which was multiplied in tomato plants of the cultivar Kada (group Santa Cruz), during three months, in 3-liter pots containing a fulvic neosol (clay: $9 \mathrm{dag} / \mathrm{kg}$, sand: $86 \mathrm{dag} / \mathrm{kg}$, silt: $5 \mathrm{dag} / \mathrm{kg}, \mathrm{pH}: 7.1$ ), which was previously autoclaved at $120^{\circ} \mathrm{C}$ for 20 minutes. After 60 days, eggs of $M$. incognita race 3 were extracted, according to the methodology of Hussey and Barker modified by Boneti and Ferraz (1981). The final suspension was calibrated to 4,500 eggs $/ \mathrm{mL}$ plus 500 second-stage juveniles $(\mathrm{J} 2) / \mathrm{mL}$ in a Peters' chamber under an optical microscope. The J2 of the nematode were obtained by placing the suspension of eggs in hatching chambers on Petri dishes (9 $\mathrm{cm}$ diameter), which were subjected to incubation at $28{ }^{\circ} \mathrm{C}$. After 48 hours, the hatched $\mathrm{J} 2$ were taken and subjected to calibration to $500 \mathrm{~J} 2 / \mathrm{mL}$ in an inverted microscope. The viability of the inoculum of $M$. incognita race 3 was confirmed by presence of galls and egg masses and by death of the tomato plants at 75 days after soil infestation with eggs and $\mathrm{J} 2$ of the pathogen. However, the number of such variables was not quantified due to deformation of the root system and 
death of the plants.

The inoculum of $F$. solani used in the experiment was the isolate Fs 19 (isolated from passion fruit plants) from the fungus collection of the Laboratory of Phytopathology of the UNIMONTES. The isolate (Fs19) obtained from passion fruit plants was tested regarding its pathogenicity. The identification of the isolate was carried out morphologically under a microscope, according to Leslie and Summerell (2006), and molecularly by sequencing of rDNA, using ITS1/ITS4 (WHITE et al, 1990). The fungus was subsampled to a synthetic nutrient agar (SNA) culture medium, which was maintained at $25{ }^{\circ} \mathrm{C}$ in a BOD incubator under absence of light for 7 days. Then, $40 \mathrm{~mL}$ of sterilized distilled water were added to the Petri dishes and, with the aid of a brush, the conidia were disaggregated. The suspension was filtered in a sterilized gauze, and the concentration of spores was calibrated in a hemacytometer to $1 \times 10^{6}$ spores $/ \mathrm{mL}$ (CARVALHO, et al., 2021; ROCHA, et al., 2018; SILVA, et al., 2013).

The seedlings of the passion fruit genotypes were grown in 24-cell polyethylene trays containing a substrate $\left(\right.$ Bioplant $\left.^{\circledR}\right)$. The experiment was implemented using seedlings that had three to six true leaves. The plants were inoculated with $F$. solani by immersing the plant roots in cups containing $30 \mathrm{ml}$ of spore suspension $\left(10^{6}\right.$ spores/ $\mathrm{mL}$ ), during 10 minutes. After this period, the plants were transplanted into $300-\mathrm{mL}$ disposable cups containing autoclaved soil, which were watered with the conidia suspension used in the inoculation. Plants not inoculated with the fungus were transplanted directly into the cups and watered with $30-\mathrm{mL}$ sterilized distilled water. Subsequently, 4,500 eggs + $500 \mathrm{~J} 2$ (initial population $=\mathrm{Pi}$ ) of $M$. incognita race 3 were inoculated, using a $5-\mathrm{mL}$ suspension, and distributed in three holes of approximately $3 \mathrm{~cm}$ depth around the plants, according to each treatment.

After five days, the seedlings were transplanted into 3-liter pots containing a Usticfluvent soil (clay: $9 \mathrm{dag} / \mathrm{kg}$, sand: $86 \mathrm{dag} / \mathrm{kg}$, silt: $5 \mathrm{dag} / \mathrm{kg}$, and $\mathrm{pH}: 7.1$ ), which was previously autoclaved at $120{ }^{\circ} \mathrm{C}$ for 20 minutes. The following nematological variables were evaluated at 180 days of inoculation: number of galls, number of egg masses, number of eggs per root system (final population=Pf), number of $\mathrm{J} 2$ in the soil, and reproduction factor $(\mathrm{RF}=\mathrm{Pf} / \mathrm{Pi})$. The egg masses were quantified after coloration with phloxin $\mathrm{B}$. The eggs were extracted according to the methodology described above and quantified in a Peters' chamber under an optical microscope. The number of $M$. incognita $\mathrm{J} 2$ present in the soil was counted after the extraction of them in $200 \mathrm{~cm}^{3}$ of soil from each pot, according to the method of Jenkins (1964), and the counting was done in a Peters' chamber under an optical microscope with $10 \times$ objective.

The reaction of the species of the passion fruit plants to the nematode was determined by the following criteria: Oostenbrink (1966), which considers the nematode reproduction factor $(\mathrm{RF}=\mathrm{Pf} /$ Pi); Taylor and Sasser (1978), which classify the reaction of plants based on the number of galls and/ or egg masses; and Moura and Régis (1987), which consider the decrease in the nematode reproduction factor in relation to the more susceptible host. According to Oostenbrink (1966), plants that cause $\mathrm{RF}=0, \mathrm{RF}<1$, and $\mathrm{RF} \geq 1$ are classified as immune, resistant, and susceptible, respectively. According to the classification of Taylor and Sasser (1978), plants whose root systems present 0 to 2 galls are considered resistant, plants with 3 to 10 galls are moderately resistant (MR), plants with 11 to 30 galls are moderately susceptible (MS), and plants whose root system presents 31 or more galls are considered susceptible (S). According to Moura and Régis (1987), plants presenting $100 \%$ decrease in RF of nematode are classified as highly resistant or immune (HR or I), plants presenting 96 to $99 \%$ decrease in RF are resistant (R), plants presenting 76 to $95 \%$ decrease in RF are moderately resistant (MR), plants presenting 51 to $75 \%$ decrease in RF are as slightly resistant (PR), plants presenting 26 to $50 \%$ decrease in RF are susceptible (S), and plants presenting $25 \%$ decrease in RF are highly susceptible (AS). For the calculation of decrease in the reproduction factor (DRF), the highest RF was considered standard of susceptibility ( $0 \%$ decrease).

Longitudinal cuts were made in roots and stems of the plants to verify presence of disease symptoms caused by $F$. solani and to measure the lesions. For the confirmation of presence of $F$. solani, fragments of injured area were removed from the plants, disinfested in 70\% alcohol and $0.1 \%$ sodium hypochlorite solution, and washed three times in sterilized distilled water. Subsequently, these fragments were placed in a SNA medium on Petri dishes. After four days, the presence of fungus was confirmed, under an optical microscope, by occurrence of morphological structures known as false heads (LESLIE; SUMMERELL, 2006).

The statistical analysis was done using the software Sisvar (FERREIRA, 2008). The data obtained were subjected to analysis of variance and the means were compared by the Scott-Knott test at $5 \%$. The $\mathrm{J} 2$ data were transformed to $\sqrt{\mathrm{x}}+0.5$ for the statistical analysis.

\section{RESULTS AND DISCUSSION}

Analysis of variance for nematological variables was done only for five of the 10 passion fruit genotypes evaluated, since the plants of the other genotypes died before the evaluations, which indicates high susceptibility of such plant materials to the nematode $M$. incognita race 3 . 
Among the viable genotypes, significant effect was found for the parameters number of galls, egg masses, eggs, J2, and reproduction factor (RF) $(p<0.01)$. The results showed no significant effect of the interaction between genotypes and pathogens and no significant effect of pathogens on such variables. Among the genotypes evaluated, $P$. giberti presented the highest number of galls, number of egg masses, number of eggs, number of J2, and RF (Table 1).

Table 1. Means for number of galls (NG), number of egg masses (NEM), and number of eggs (NE) per root system, number of $\mathrm{J} 2$ per $200 \mathrm{~cm}^{3}$ of soil, reproduction factor (RF), and percentage of decrease in reproduction factor (DRF) of Meloidogyne incognita raça 3 in genotypes of passion fruit plants (Passiflora spp.), evaluated at 180 days after inoculation.

\begin{tabular}{ccccccc}
\hline Genotypes & NG & NEM & NE & J2 $^{\mathrm{x}}$ & FR & DRF(\%) \\
\hline 'BRS Sol do Cerrado' & $0.58 \mathrm{a}$ & $0.00 \mathrm{a}$ & $103.91 \mathrm{a}$ & $0.00 \mathrm{a}$ & $0.02 \mathrm{a}$ & 99.90 \\
M-19-UFV & $1.91 \mathrm{a}$ & $0.00 \mathrm{a}$ & $213.00 \mathrm{a}$ & $0.00 \mathrm{a}$ & $0.04 \mathrm{a}$ & 99.80 \\
P. alata & $4.41 \mathrm{a}$ & $0.00 \mathrm{a}$ & $274.66 \mathrm{a}$ & $0.00 \mathrm{a}$ & $0.05 \mathrm{a}$ & 99.75 \\
P. cinccinata & $21.00 \mathrm{a}$ & $14.91 \mathrm{a}$ & $3295.75 \mathrm{a}$ & $11.58 \mathrm{~b}$ & $0.65 \mathrm{a}$ & 96.75 \\
P. giberti & $351.33 \mathrm{~b}$ & $340.50 \mathrm{~b}$ & $100085.83 \mathrm{~b}$ & $25.00 \mathrm{c}$ & $20.01 \mathrm{~b}$ & 0.00 \\
\hline CV & 38.67 & 40.80 & 38.37 & 48.04 & 38.37 & \\
\hline $\mathrm{F}$ (Genotypes) & $* * 331.68$ & $* * 324.21$ & $* * 370.67$ & $* * 33.72$ & $* * 370.67$ \\
\hline
\end{tabular}

Means followed by same letter in the column are not significantly different $(\mathrm{P} \geq 0.05)$ by the Scott-Knott teste at 5\%.

${ }^{\mathrm{x}}$ For the statistical analysis, the data were transformed to $\sqrt{\mathrm{x}}+0.5$. $* *(\mathrm{p}<0.01)$. Decrease in reproduction factor $(\mathrm{DRF})=$ (standard RF - RF of the treatment)/standard RF.

Regarding the reaction of the genotypes to $M$. incognita race $3, P$. giberti was considered susceptible and highly susceptible, according to the criteria of Oostenbrink (1966) and Moura and Regis (1987), respectively. The genotypes BRS Sol do Cerrado, M-19-UFV, $P$. alata, and $P$. cinccinata presented resistance to the pathogen, according to both criteria (Table 2).

According to the criterion of Taylor and Sasser (1978), 'BRS Sol do Cerrado' and M-19-UFV were resistant, $P$. alata was moderately resistant, $P$. cinccinata was moderately susceptible, and $P$. giberti was susceptible (Table 2). P. giberti, classified as moderately resistant by the criterion of Moura and Regis (1987), was evaluated by Rocha et al. (2013) and classified as highly susceptible and, in the experiment conducted by these authors, was adopted as standard of susceptibility.

Table 2. Reaction of genotypes of passion fruit plants (Passiflora spp.) to Meloidogyne incognita race 3 (Mi), evaluated at 180 days after inoculation.

\begin{tabular}{cccc}
\hline & C.O & C.M.R & C.T.S \\
\cline { 2 - 4 } Genotypes & M.i & M.i & M.i \\
\hline 'BRS Sol do Cerrado' & $\mathrm{R}$ & $\mathrm{R}$ & $\mathrm{R}$ \\
M-19-UFV & $\mathrm{R}$ & $\mathrm{R}$ & $\mathrm{R}$ \\
P. alata & $\mathrm{R}$ & $\mathrm{R}$ & $\mathrm{MR}$ \\
P. cincinnata & $\mathrm{R}$ & $\mathrm{R}$ & $\mathrm{MS}$ \\
P. giberti & $\mathrm{S}$ & $\mathrm{HS}$ & $\mathrm{S}$ \\
\hline
\end{tabular}

C.O = criterion of Oostenbrink (1966): resistant (R), susceptible (S); and immune (I).

C.M.R = criterion of Moura and Régis (1987): highly susceptible (HS); susceptible (S); slightly resistant (SR); moderately resistant (MR); resistant (R); and immune (I).

C.T.S = criterion of Taylor and Sasser (1978): resistant (R); moderately resistant (MR); moderately susceptible (MS); and susceptible (S).

The presence of galls and eggs in the plants of the genotypes BRS Sol do Cerrado, M-19-UFV, and $P$. alata, and death of five genotypes found in the present experiment, which was not found in the study of Rocha et al. (2013), can be attributed to the increase in initial inoculum and to the longer period during which the plants were in contact with the pathogen. This indicates that increases in initial inoculum can affect the reaction of passion fruit plants. 
Dong et al. (2007) evaluated resistance of seven peanut genotypes to Meloidogyne arenaria, with three levels of resistance. They found that the three resistance levels could be separated based on the index of galls found at two weeks after inoculation with 8,000 eggs of $M$. arenaria; however, when they used 1,000 to 6,000 eggs per plant, four or more weeks were required. When evaluating the resistance based on the number of eggs per gram of roots within 8 weeks, they found that more than 8,000 eggs per plant were needed to separate the three resistance levels. This denotes that the level of inoculum affects the time for the plant resistance reaction and that the methodology for evaluation using index of galls reduces the time and the level of inoculum required for the separation of resistance levels when compared to other evaluation methods. This was also found by El-Moor et al (2009) when evaluating two genotypes of passion fruit plants: Redondão and the hybrid F1 (Marília $\times$ Roxo Australiano). Both genotypes presented different dynamics regarding the model proposed by Taylor and Sasser, since the plants of Redondão and hybrid F1 were classified as moderately resistant and moderately susceptible, respectively, when inoculated with 3,000 eggs per plant; however, when they were inoculated with 6,000 and 9,000 eggs per plant, the genotypes were classified as moderately susceptible and susceptible, respectively.

Regarding the evaluation of $F$. solani, all genotypes presented at least one plant with disease symptoms caused by the fungus, except for $P$. cincinnata, which presented plants with no symptoms (Tables 3 and 4).

The symptoms found were: stem base peeling, internal orange spots in roots and stems, and internal long light-brown lesions in stems of infected plants (Figure 1). However, there was no repeatability of manifestation of symptoms within the treatments. Variations in lesion length (severity) and in incidence of plants with no symptoms were found within the same treatment (Tables 3 and 4).

Within the same genotype, some plants presented no symptoms, whereas other plants presented lesions of up to $13 \mathrm{~cm}$. Such variation in severity within a genotype can be explained by the high genetic variability of passion fruit plants from seeds, since it is an allogamous and autoincompatible species. Some studies have been showing intraspecific variability of genotypes of the genus Passiflora to F. solani (BUENO et al., 2010; FISCHER et al., 2005a).

The use of seedlings cloned from cuttings of a same individual, in further studies, may decrease this variability. Another important fact to be considered in selection tests for resistance in the pathosystem $F$. solani vs passion fruit plants is the number of pathogen isolates. Bueno et al. (2010) recommend tests using a mixture of isolates to allow exposure of the genetic material to a population of pathogens. Thus, such strategy allows for a more precise expression of the level and stability of the resistance.

Table 3. Length and frequency of lesions caused by Fusarium solani in genotypes of passion fruit plants (Passiflora spp.) at 180 days after inoculation with Fusarium solani (FS) and Meloidogyne incognita race 3 (Mi).

\begin{tabular}{ccc}
\hline \multirow{2}{*}{ Genotypes } & Length $(\mathrm{cm})$ and frequency of lesions caused by Fusarium solani \\
\cline { 2 - 3 } & $\mathrm{FS}$ & $\mathrm{FS}+\mathrm{Mi}$ \\
\hline \multirow{2}{*}{ BRS Sol do Cerrado } & $10 \mathrm{~cm}-1 / 6$ & $4 \mathrm{~cm}-1 / 6$ \\
& $\mathrm{P}-2 / 6$ & $\mathrm{P}-2 / 6$ \\
M-19-UFV & $\mathrm{P}-2 / 6$ & $7 \mathrm{~cm}-1 / 6$ \\
& $13 \mathrm{~cm}-1 / 6$ & $2 \mathrm{~cm}-1 / 6$ \\
P. alata & $10 \mathrm{~cm}-1 / 6$ & $7 \mathrm{~cm}-1 / 6$ \\
P. cincinnata & $3.6 \mathrm{~cm}-1 / 6$ & \\
P. giberti & $10 \mathrm{~cm}-1 / 6$ & $0 \mathrm{~cm}-6 / 6$ \\
& $3 \mathrm{~cm}-1 / 6$ & $\mathrm{P}-3 / 6$ \\
P. ligularis & $\mathrm{P}-3 / 6$ & \\
& $13 \mathrm{~cm}-1 / 6$ & $2.5 \mathrm{~cm}-1 / 6$ \\
P. morifolia & $2 \mathrm{~cm}-1 / 6$ & $1.3 \mathrm{~cm}-1 / 6$ \\
& $\mathrm{P}-2 / 6$ & $\mathrm{P}-3 / 6$ \\
P.mucronata & $5 \mathrm{~cm}-1 / 6$ & $3 \mathrm{~cm}-1 / 6$ \\
P. nitida & $2 \mathrm{~cm}-1 / 6$ & $1 \mathrm{~cm}-1 / 6$ \\
P. setacea & $\mathrm{P}-2 / 6$ & $\mathrm{P}-4 / 6$ \\
& $4 \mathrm{~cm}-1 / 6$ & $\mathrm{P}-1 / 6$ \\
& $7 \mathrm{~cm}-1 / 6$ & $8 \mathrm{~cm}-1 / 6$ \\
& & $2 \mathrm{~cm}-1 / 6$ \\
\hline
\end{tabular}

$\mathrm{P}=$ Points of infection by $F$. solani. 
Table 4. Lesion size variation, incidence of plants with disease symptoms caused by Fusarium solani, and plant survival of genotypes of passion fruit plants (Passiflora spp.) inoculated with Fusarium solani (FS) and Meloidogyne incognita race 3 (Mi).

\begin{tabular}{|c|c|c|c|c|c|c|c|}
\hline \multirow{2}{*}{ Genotypes } & \multicolumn{2}{|c|}{$\begin{array}{l}\text { Lesion size variation } \\
\qquad(\mathrm{cm})\end{array}$} & \multicolumn{2}{|c|}{$\begin{array}{c}\text { Incidence of diseased plants } \\
(\%)\end{array}$} & \multicolumn{3}{|c|}{ Plant survival (\%) } \\
\hline & FS & $\mathrm{Mi}+\mathrm{FS}$ & FS & $\mathrm{Mi}+\mathrm{FS}$ & FS & $\mathrm{Mi}+\mathrm{FS}$ & $\mathrm{Mi}$ \\
\hline BRS Sol do Cerrado & $0-10$ & $0-4$ & 50.00 & 50.00 & 100.00 & 100.00 & 100.00 \\
\hline M-19-UFV & $0-\mathrm{P}$ & $0-7$ & 33.33 & 33.33 & 100.00 & 100.00 & 100.00 \\
\hline P. alata & $0-13$ & $0-7$ & 50.00 & 16.67 & 100.00 & 100.00 & 100.00 \\
\hline P. cincinnata & $0-10$ & $0-0$ & 16.67 & 0.00 & 100.00 & 100.00 & 100.00 \\
\hline P. giberti & $0-3$ & 0-P & 50.00 & 66.67 & 100.00 & 100.00 & 100.00 \\
\hline P. ligularis & $0-13$ & $0-2.5$ & 66.67 & 83.33 & 66.67 & 0.00 & 0.00 \\
\hline P. morifolia & $0-5$ & P-3 & 66.67 & 100.00 & 100.00 & 0.00 & 0.00 \\
\hline P.mucronata & $0-4$ & 0-P & 16.67 & 16.67 & 100.00 & 0.00 & 0.00 \\
\hline P. sharp & $0-7$ & $0-8$ & 16.67 & 33.33 & 100.00 & 0.00 & 0.00 \\
\hline P. setacea & $0-\mathrm{P}$ & 0-P & 33.33 & 33.33 & 100.00 & 0.00 & 0.00 \\
\hline
\end{tabular}

$\mathrm{P}=$ Points of infection by $F$. solani.

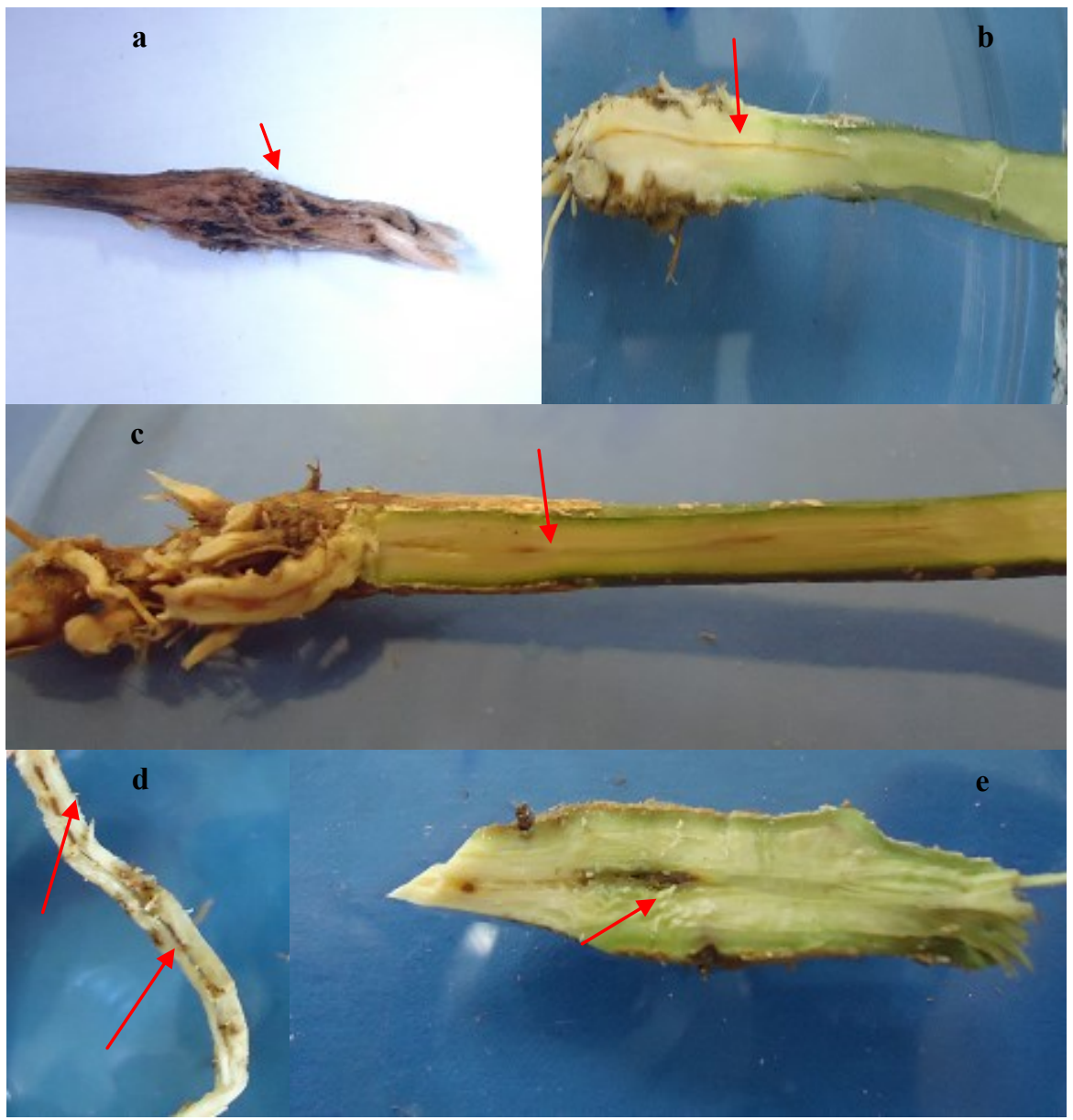

Figure 1. Disease symptoms caused by Fusarium solani in genotypes of passion fruit plants: a) peeling of the cortex at the stem base of Passiflora ligularis plant; b) internal spot in a passion fruit plant of the hybrid BRS Sol do Cerrado; c) internal spot in root and stem in a passion fruit plant of the genotype M-19-UFV; d) internal spot in root of a Passiflora alata plant; e) internal spot in stem of a Passiflora morifolia plant.

The lesion length data were not subjected to analysis of variance because they did not meet the basic statistical assumptions (normality, additivity, and homogeneity), thus, the results were presented descriptively (Tables 3 and 4). The genotypes 'BRS Sol do Cerrado', $P$. alata, $P$. cincinnata, and $P$. 
ligularis inoculated only with $F$. solani presented the largest lesions, which varied from 0 to $10 \mathrm{~cm}$ and from 0 to $13 \mathrm{~cm}$. In the presence of both pathogens, the genotypes M-19-UFV, $P$. alata, and $P$. nitida presented the largest lesions: 7, 7, and $8 \mathrm{~cm}$, respectively. In the presence of $F$. solani or $M$. incognita race $3+F$. solani, $P$. setacea plants presented only points of infection, presenting no symptoms of internal spots, which denotes the potential of using such plant material as rootstocks for yellow passion fruit plants in areas infested by these pathogens. Plants of $P$. cincinnata, $P$. giberti, and $P$. mucronata present no development of lesions after inoculation with the fungus and the nematode simultaneously. Fischer et al. (2005a) found that the genotypes $P$. alata, $P$. morifolia, and $P$. nitida presented higher level of resistance than the genotypes $P$. cincinnata, $P$. setacea, and $P$. giberti, considering the mean value of the lesions found.

Regarding the incidence of diseased plants (Table 4), all genotypes that presented resistance to the nematode ('BRS Sol do Cerrado', M-19-UFV, $P$. alata, and $P$. cincinnata) after inoculation with $F$. solani showed a higher or equal percentage of plants with symptoms when compared to those subjected to the treatment with $M$. incognita race $3+F$. solani. However, the genotypes susceptible to the nematode when inoculated with both pathogens presented higher or equal percentage of plants with symptoms caused by the fungus than those in the treatment consisting of inoculation only with the fungus. This result denotes that the nematode facilitated the infection by the fungus probably due to the wounds caused by the penetration of $M$. incognita race 3 in the plant root. Thus, when using genotypes that have some level of susceptibility to the nematode, the incidence of diseases caused by the fungus increases when these genotypes are subjected to joint infection by $M$. incognita race 3 and $F$. solani, which was found for the genotypes $P$. giberti, $P$. nitida, $P$. ligularis, and P. morifolia (Table 3).

Regarding the interaction Fusarium Meloidogyne, several studies already confirmed that the nematode makes the plants more prone to infection by the fungus (ROCHA, et al., 2018, GOMES, et al., 2011, SILVA; PEREIRA, 2008). There are still no consistent results showing the interaction between $M$. incognita and $F$. solani in passion fruit crops.

The incidence of plants with symptoms caused by the fungus ranged from 0 to $50 \%$ in the genotypes resistant to the nematode and subjected to the two pathogens, and ranged from 16.67 to $50 \%$ in those that were subjected only to the fungus. However, in the genotypes susceptible to $M$. incognita race 3, the variation was from 16.67 to $100 \%$ in the presence of both pathogens, and from 16.67 to $66.67 \%$ in the presence of the fungus. The genotypes that presented lower incidence of plants with symptoms were $P$. mucronata, $P$. nitida, $P$. setacea, $P$. cincinnata, and M-19-UFV, showing higher resistance to the fungus when compared to the other genotypes. Roncatto et al. (2004) studied the dynamics of genotypes of passion fruit plants regarding resistance to $F$. solani and found that $P$. giberti and $P$. nitida were resistant to diseases caused by this fungus. Fischer et al. (2005b) also reported the resistance of $P$. mucronata plants to $F$. solani. However, among the five genotypes that presented lower incidence of plants with symptoms caused by the fungus, only $P$. cincinnata and M-19-UFV presented resistance to the nematode.

Except for $P$. giberti, all the other genotypes susceptible to $M$. incognita race 3 presented $0 \%$ plant survival when infected with the nematode, regardless of the treatment ( $M$. incognita race 3 or $M$. incognita race $3+F$. solani). No similar result was found for the plants infected only with the fungus, since a $66.67 \%$ survival was found for $P$. ligularis plants. Not all plants of $P$. morifolia, $P$. mucronata, $P$. nitida, and $P$. setacea that died after inoculation with the two pathogens presented symptoms caused by the fungus, indicating that the death of plants was due to the presence of the nematode (Table 2; Figure 2). The other genotypes resistant to the nematode, had $100 \%$ plant survival, regardless of the inoculation with $F$. solani or M. incognita race 3.

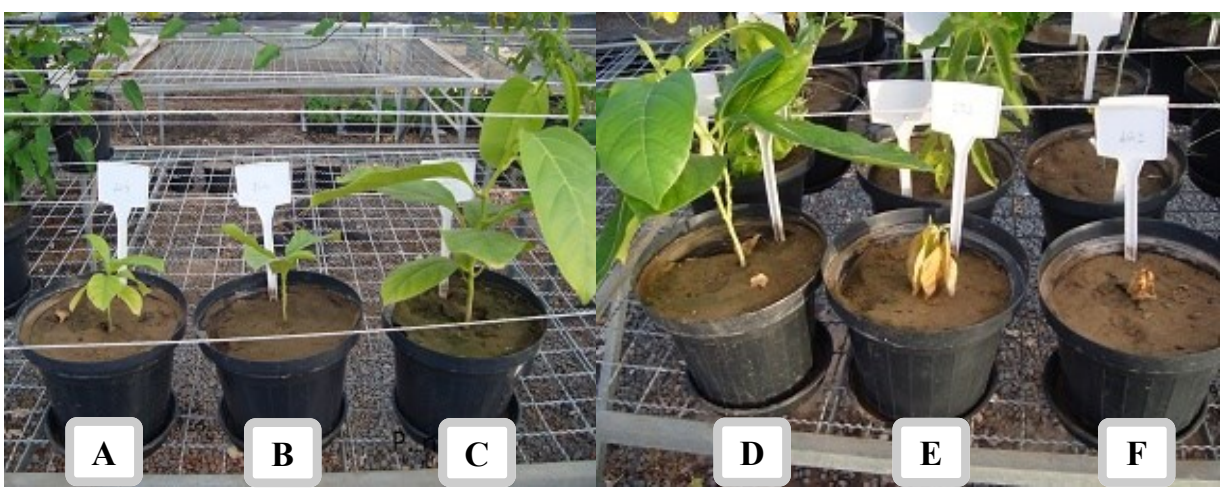

Figure 2. Plants of Passiflora nitida at 75 days after inoculation with Meloidogyne incognita race 3 and Fusarium solani. A, F - Meloidogyne incognita race 3; B, E - Meloidogyne incognita race $3+$ F.solani; C, D - Fusarium solani.

Rev. Caatinga, Mossoró, v. 34, n. 3, p. 605 - 613, jul. - set., 2021 
The presence of the fungus was confirmed in all samples of plants with symptoms, since false heads were found in the fungus mycelium after the re-isolation (Figure 3).
The genotypes M-19-UFV and $P$. cincinnata present potential for use as rootstock for yellow passion fruit plants focused on to the control of $M$. incognita race 3 and $F$. solani.

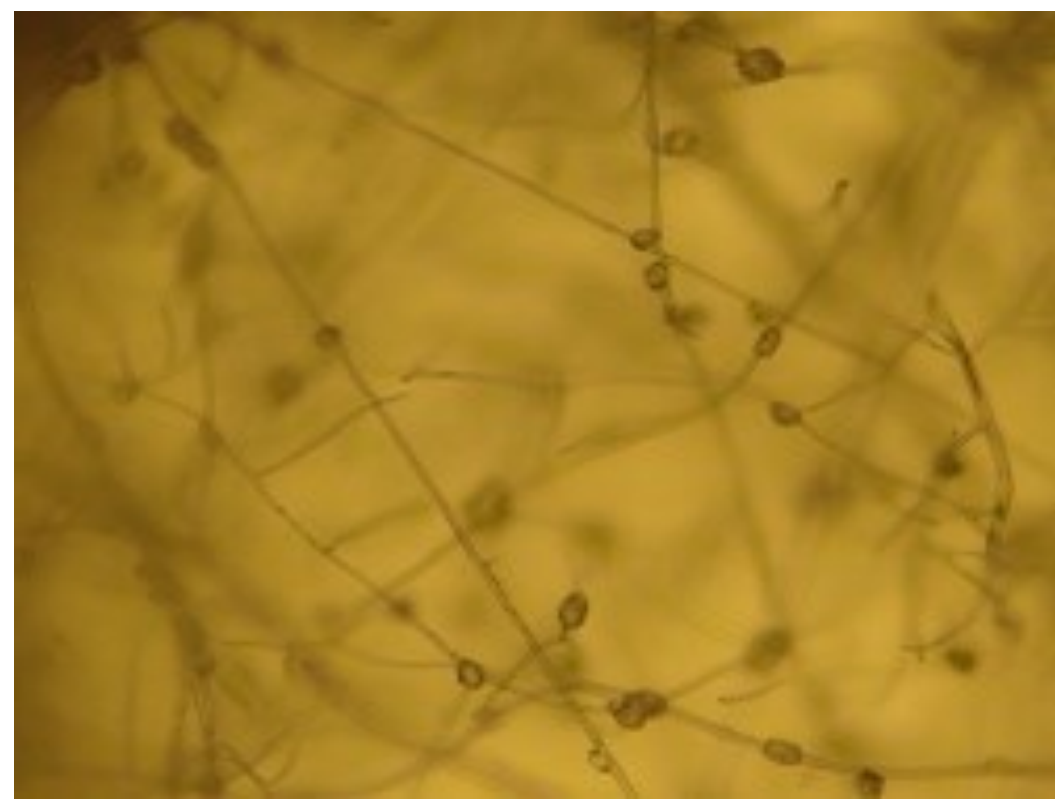

Figure 3. A - Morphological structures known as false heads of Fusarium solani.

\section{CONCLUSIONS}

The passion fruit genotypes BRS Sol do Cerrado, M-19-UFV, Passiflora alata, and $P$. cincinnata are resistant to $M$. incognita race 3 .

The genotypes $P$. nitida, $P$. setacea, $P$. mucronata, $P$. morifolia, and $P$. ligularis are highly susceptible to $M$. incognita race 3.

The genotypes M-19-UFV, $P$. giberti, $P$. setacea, $P$. mucronata, and $P$. cincinnata present higher level of resistance to $F$. solani.

\section{REFERENCES}

ABD-EL-FATTAH, T. I. et al. Interaction of Fusarium solani and Meloidogyne incognita on sugar beet and their control using Trichoderma viride. Journal of Applied Sciences Research, 8: 3166-3175, 2012.

BONETI, J. I. S.; FERRAZ, S. Modificação of method of Hussey and Barker for extraction of eggs of Meloidogyne exigua of coffee plants. Phytopathology Brazilian, 6: 553-553, 1981.

BUENO, C. J et al. Comportamento do maracujazeiro amarelo, variedade Afruvec, ante uma população de Fusarium solani, agente causal da podridão-do-colo. Arquivo Instituto Biológico, 77:
$533-537,2010$

CARNEIRO, F. F.; RAMALHO, M. P.; PEREIRA, M. J. Z. Fusarium oxysporum f. sp. phaseoli and Meloidogyne incognita interaction in common bean. Crop Breeding and Applied Biotechnology, 10: 271-274, 2010.

CASTRO, A. P. G. et al. Resistência de genótipos comerciais e silvestres de Passiflora spp. a Meloidogyne incognita em condições de casa de vegetação. Revista da Faculdade de Zootecnia, Veterinária e Agronomia, 17: 186-198, 2010.

CARVALHO, et al. Passion Fruit (Passiflora spp.) species as sources of resistance to soil phytopathogens Fusarium solani and Fusarium oxysporum f. sp. passiflorae complex. Revista Brasileira Fruticultura, 43: 1-9, 2021.

CHITWOOD, B. G. 'Root-knot nematodes'. Part 1. A revision of the genus Meloidogyne Goeldi, 1887. Proceedings of the Helminthological society of Washington, 16: 90-114, 1949.

DARIVA, J. M. Fusarioses do maracujazeiro: etiologia e sintomatologia. 2011. 71 f. Dissertação (Mestrado em Produção Vegetal: Área de Concentração em Fitossanidade) - Universidade Estadual de Montes Claros, Janaúba, 2011. 
DONG, W. et al. Comparison of methods for assessing resistance to Meloidogyne arenaria in peanut. Journal of Nematology, 39: 169-175, 2007.

EL-MOOR, R. D. et al. Reaction of genotypes of passion fruit plant sour to the root-knot nematodes (Meloiodgyne incognita and Meloidogyne javanica). Bioscience Journal, 25: 53-59, 2009.

FALEIRO, F. G.; JUNQUEIRA, N. T. V.; BRAGA, M. F. Maracujá: demandas para a pesquisa. 1. ed. Planaltina, DF: Embrapa Cerrados, 2006, 54 p.

FERREIRA, D. F. SISVAR: um programa para análises e ensino de estatística. Revista Symposium, 6: 36-41, 2008.

FISCHER, I. H. et al. Reaction of passion fruit plantyellow to the complex of fusariose-nematode of branch |knot|. Acta Scientiarum Agronomy, 2: 223$227,2010$.

FISCHER, I. H. et al. Seleção de plantas resistentes e de fungicidas para o controle da podridão-do-colo do maracujazeiro causada por Nectria hematococca. Fitopatologia Brasileira, 30: 250-258, 2005a.

FISCHER, I. H. et al. Ocorrência of Nectria haematococca in maracujazais in the state of Rio de Janeiro and resistance of Passiflora mucronata to the pathogen. Phytopathology Brazilian, 30: 671, $2005 b$.

FISCHER, I. H. et al. Ocorrência de Nectria haematococca em ma-racujazais no estado do Rio de Janeiro e resistência de Passiflora mucronata ao patógeno. Fitopatologia Brasileira, 30: 671-671, $2005 b$

GARCIA, M. J. D. M. et al. Reação de maracujazeiro amarelo 'Afruvec' e 'Maguary' a Meloidogyne spp. Arquivos do Instituto Biológico, 75: 235-238, 2008.

GOMES, M. G. et al. Guava decline: the complex disease involving Meloidogyne mayaguensis and Fusarium solani. Journal of Phytopathology, 159: 45-50, 2011.

IBGE - Institute Brazilian of Geography and statistical. 2019. Data demográficos and production agricultural municipal. Available in: $<$ https://cities.ibge.gov.br/brasil/research/15/0 > Acesso in: 04 May. 2021.

JENKINS, W. R. The rapid centrifugal- flotation technique for separating nematodes from soil. Plant Disease Reporter, 48: 692-692, 1964.
LESLIE, J. F.; SUMMERELL, B. The Fusarium laboratory manual. v. 2. n. 10. Blackwell Pub., 2006.

MOURA, R. M.; REGIS, E. M. O. Reações de feijoeiro comum (Phaseolus vulgaris) em relação ao parasitismo de Meloidogyne javanica e M. incognita (Nematoda: Heteroderidae). Nematologia Brasileira, 10: 215-225, 1987.

OOSTENBRINK, M. Major characteristics of the relation between nematodes and plants. Mededelingen, 66: 1-46, 1966.

PONTE, J. J. et al. Calagem, adubação orgânica e fungicida de solo no controle da podridão do pé (Fusarium solani) do maracujá amarelo Fitopatologia Venezolana, 12: 30-31, 1998.

ROCHA, L. S. et al. Reação de genótipos de maracujazeiro a Meloidogyne incognita raça 3 e Meloidogyne javanica. Revista Brasileira de Fruticultura, 35: 1017-1024, 2013.

ROCHA. L. S. et al. Reaction of cultivars of banana tree to the complex Meloidogyne javanica $\mathrm{X}$ Fusarium oxysporum f. sp. cubense. Revista Caatinga, 31: 572 -583, 2018.

RONCATTO, G. et al. Comportamento de maracujazeiros (Passiflora spp.) quanto à morte prematura. Revista Brasileira de Fruticultura, 26: $552-554,2004$

SILVA, G. S.; PEREIRA, A. L. Efeito da incorporação de folhas de nim ao solo sobre o complexo Fusarium x Meloidogyne em quiabeiro. Summa phytopathologica, 34: 368-370, 2008.

SILVA, et al. Identification of passion fruit genotypes resistant to Fusarium oxysporum f. sp. passiflorae. Tropical Plant Pathology, 38: 236-242, 2013.

TAYLOR, A. L.; SASSER, J. N. Biology, identification and control of root-knot nematodes (Meloidogyne species). Raleigh: North Caroline State University, 1978. $111 \mathrm{p}$

WHITE, T. J. et al. Amplification and direct sequencing of fungal ribosomal RNA genes for phylogenetics. In: INNIS, M. A.; GELFAND, D. H.; SNINSKY, J. J.; WHITE, T. J. (Eds.). PCR protocols: the guide to methods and applications. San Diego, CA: Academic Press, 1990. v. 1, p. $315-$ 322 